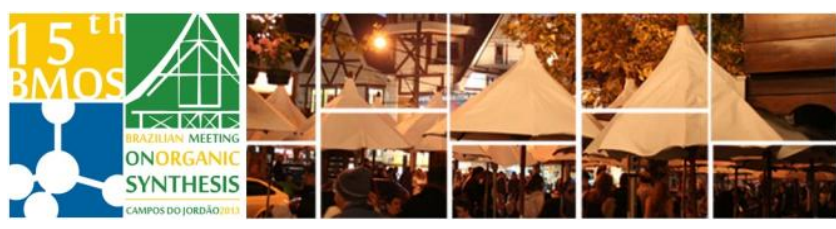

\title{
Synthesis of new naphthotriazoles derived from juglone as
} anticancer agents

\author{
Wanderson A. da Silva ${ }^{a}$, Vinicius N. Moreira ${ }^{a}$, Vinícius R. Campos ${ }^{a}$, Vitor F. \\ Ferreira, David R. da Rochaa, Jackson A. L. C. Resende ${ }^{b}$, Raquel C. Montenegro ${ }^{c}$, \\ Maria Cecília B. V. de Souza ${ }^{a}$, and Anna C. Cunha ${ }^{a^{*}}$
}

\author{
aUniversidade Federal Fluminense, Departamento de Química Orgânica, Programa de Pós-Graduação em \\ Química, Outeiro de São João Batista, 24020-141 Niterói, RJ, Brasil \\ ${ }^{b}$ Universidade Federal Fluminense, Departamento de Química Inorgânica, Programa de Pós-Graduação em \\ Química, Outeiro de São João Batista, 24020-141 Niterói, RJ, Brasil \\ 'Universidade Federal do Pará, Instituto de Ciências Biológicas, Belém, PA, Brasil.
}

*corresponding author. Tel.: +55 21 26292364; Fax: +55 21 26292135; e-mail: annac@vm.uff.br

Keywords: triazole, anticancer activity and juglone

\section{INTRODUCTION}

Juglone (3) is a natural compound isolated from nogueira plants (Juglans nigra) which has shown important cytotoxic activity ${ }^{1}$. Quinones fused to $N$ heterocyclic aromatic rings have been reported in the literature ${ }^{2}$ as potential anticancer agents.

On the basis of our experience in the field of the synthesis and biological evaluation of new quinonecarbohydrate conjugates $^{3}$ and 1,2,3-triazole derivatives, we described the synthesis and in vitro anticancer activity studies of new compounds type 1 in which Juglone and 1,2,3-triazole frameworks are directly attached (Scheme).

\section{RESULTS AND DISCUSSION}

The thermal 1,3-dipolar cycloaddition reaction between glycosyl azides 2a-b and juglone (3) afforded corresponding 5-hydroxy-1-substituted-1Hnaphtho[2,3-d][1,2,3-]triazole-4,9-diones $\mathbf{1 a - b}$, in moderated yields, and unexpected naphthoquinone derivatives $\mathbf{4 a - b}$, which possess an aminocarbohydrate chain at the C-2 position of the quinone ring.
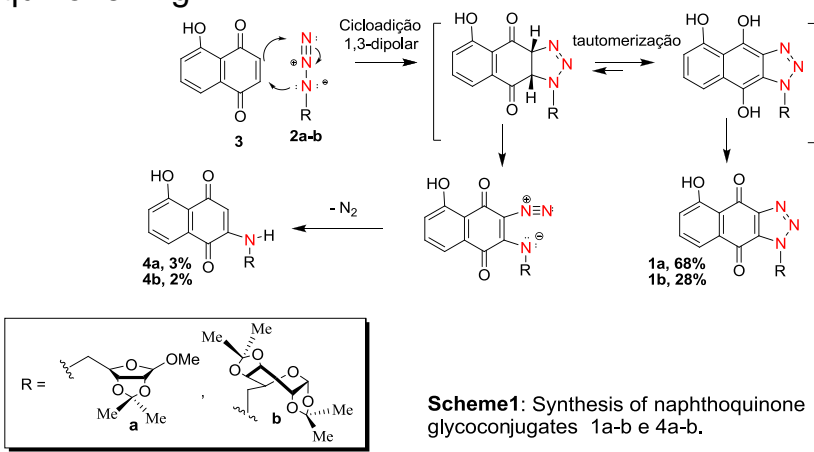

Scheme1: Synthesis of naphthoquinone glycoconjugates $1 a-b$ e $4 a-b$.

The regiochemistry of the reactions was determinated on the basis of X-ray crystallographic data of the molecular structures of compounds 1a and $\mathbf{4 a}$.
The in vitro anticancer activity of the new Juglone derivatives $\mathbf{1} \mathbf{a}-\mathbf{b}$ and $\mathbf{4 a - b}$ were assessed against HL-60, MDA-MB 435, HCT-116, SF-295, A-549 and OVCAR-8 human cancer cell lines.

Among the $\mathbf{1} \mathbf{a}-\mathbf{b}$ and $\mathbf{4 a - b}$, only the naphthotriazole compounds $\mathbf{1 a}$ and $\mathbf{1 b}$ showed potential activity $\left(\mathrm{IC}_{50}\right.$ below $\left.1.0 \mu \mathrm{g} / \mathrm{mL}^{-1}\right)$ against five cell lines.

\section{CONCLUSION}

The cycloaddition reaction of the glycosyl azides 2ab with Juglone (3) furnished the corresponding naphthotriazole derivatives $\mathbf{1} \mathbf{a}-\mathbf{b}$ in moderated yields, together with unexpected aminonaphthoquinones 4a-b.

The compounds $\mathbf{1 a}$ and $\mathbf{1 b}$ were screened for their anticancer activity and exhibited an expressive cytotoxic effect against five cancer cell lines.

To analyze the eventual effect of the pharmacophoric 1,2,3-triazole moiety fused to homoaromatic ring, we also evaluated the biological activity of the aminonaphthoquinones $\mathbf{4 a}$ and $\mathbf{4 b}$. They weren't citotoxic against all tested cancer cell lines. This result shows that the aza-heterocyclic moiety conjugated with naphthoquinone ring is a considerably important factor that confers anticancer activity of new quinone derivatives $\mathbf{1 a}$ and $\mathbf{1} \mathbf{b}$.

\section{ACKNOWLEDGEMENTS}

This work was supported by the Brazilian agency FAPERJ-Pronex. Fellowship granted to UFF, by FAPERJ, Capes, CNPq-PIBIC is gratefully acknowledged.

\section{REFERENCES}

Silva, M. N.; Ferreira, V. F.; Souza, M. C. B. V., Quím. Nova 2003, 26, 407.

2Oliveira,R.B.A., José, R., Quím. Nova 2002, 25, 976.

${ }^{3}$ Ferreira, V. F.; Jorqueira, A.; Souza, A. M. T; Silva, M. N.; Souza, M. C. B. V.; Gouve, R. M.; Rodrigues, C. R.; Pinto, A. V.; Castro, H. C.; Santos, D. O.; Araújo, H. P.; Bourguignon, S. C., Bioorg. Med. Chem. 2006, 14, 5459. 